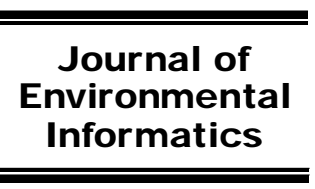

www.iseis.org/jei

\title{
Simulating Hydrologic Impacts of Urban Growth Using SLEUTH, Multi Criteria Evaluation and Runoff Modeling
}

\author{
A. S. Mahiny ${ }^{1 *}$ and K. C. Clarke ${ }^{2}$ \\ ${ }^{1}$ Department of the Environment, Gorgan University of Agricultural Sciences and Natural Resources, Gorgan, Golestan 49138-15749, Iran \\ ${ }^{2}$ Department of Geography, University of California, Santa Barbara CA 93106-4060, USA
}

Received 19 November 2011; revised 14 July 2013; accepted 6 September 2013; published online 25 September 2013

\begin{abstract}
Research on the sustainability of future urban environments has shown not only the value of simulation modeling, but also the strength of coupling their forecasts together into loosely integrated models. In this research we propose a way to improve modeling of urban futures by using enhanced land use change modeling as an input to a hydrological model. Our forecasts of hydrologic impacts are based on the L-THIA model, but this model is sensitive in turn to the land uses associated with urbanization, especially impervious surfaces and other urban uses. In order to improve the performance of the SLEUTH land use/cover change model, we modified one of that model's inputs using multi-criteria evaluation (MCE). The data basis for the modeling used land cover classes mapped for the years 1987, 1992, 2000 and 2005 in the Gorgan Township of northeastern Iran using Landsat TM and ETM+ remotely sensed images. A hybrid unsupervised, supervised and on-screen classification method was used to generate land use/cover maps of the area. To test the value of enhanced modeling, we compared the results from three model forecasts of the year 2040, an original SLEUTH forecast, an urban suitability-informed SLEUTH forecast, and a hydrologic plus urban suitability-informed SLEUTH forecast. As a control, we also used standard MCE to forecast urban growth for the year 2040. The integrated model comparison was made based on two future urban landscape descriptors: (1) potential surface runoff volume; and (2) landscape metrics. Results indicate that the integrated modeling approach produces a land use arrangement through SLEUTH that can be better directed towards higher land suitability and more favorable hydrologic conditions. The results for the combined hydrologic plus urban suitability-informed SLEUTH modeling were superior to the other three methods in terms of lower potential for runoff volume generation and more sustainable landscape metrics of shape, size and proximity. We demonstrate that the self-organizing cellular automata method behind SLEUTH is capable of better informed land use planning when compared to the simple MCE method. The approach can also be improved by using suitability layers for other land use practices to achieve a more comprehensive land use plan.
\end{abstract}

Keywords: SLEUTH, land use/cover change, L-THIA, MCE, urban suitability

\section{Introduction}

Freshwater is an essential and scarce natural resource of the earth upon which human life and that of most fauna and flora depends. Of all the water of the earth, $97.5 \%$ is saline and only $2.5 \%$ is fresh and of this only $29.9 \%$ exists as fresh groundwater and a tiny $0.3 \%$ is concentrated in lakes, reservoirs and river systems where they are most easily accessible. The remainning $0.9 \%$ is found in swamps, soil moisture and permafrost (Gleick, 1996; Postel et al., 1996; Shiklomanov, 1999; Gleick, 2000). These accessible supplies must serve not only humanity's economic and survival needs, but also many of earth's freshwater-based ecosystems (UNESCO, 2010). Freshwater reserves are being rapidly depleted due to climate warming, land conversion, irrigation, forest clearing, river course

\footnotetext{
${ }^{*}$ Corresponding author. Tel.: +98 1712245965; fax: +98 1712245886 .

E-mail address: a_mahini@yahoo.com (A. S. Mahiny).
}

ISSN: 1726-2135 print/1684-8799 online

(C) 2013 ISEIS All rights reserved. doi:10.3808/jei.201300243 alteration and a host of other human activities (Gleick et al., 2001). To manage and replenish freshwater resources, land use/cover management plans are being implemented worldwide together with reforestation and vegetation restoration practices to decrease surface runoff and increase infiltration (see for example Scanlon et al., 2007; Cao et al., 2008; Randhir and Tsvetkova, 2011). Studies have also shown the effect of urban development on runoff and other aspects of the water cycle (Poelmans et al., 2010; Yeo et al., 2004).

In this research we seek to test how a water regime in the future is impacted by urban development and land use change. We first created a test system in which the L-THIA hydrological model was provided with different input layers generated by a land use change model, SLEUTH. SLEUTH, in turn, was calibrated and used based on three different weighted input layers known as exclusion layers. The exclusion layers are weighted input layers that reflect the spatially disaggregated restrictions to be placed on land modification. Three layers were created, an unweighted layer, a layer given weights assigned by Multicriteria Evaluation (MCE), and a third that also incorporated a water protection strategy. This also allowed MCE alo- 
ne to be used as a forecast model. The goal was to objectively compare the impacts of each input layer on the hydrologic forecasts, and on landscape metrics that described the geometry, and hence the sustainability, of the forecast land use pattern.

In just over one hundred years, the proportion of the world's population living in urban areas has increased from approximately $15 \%$ to over $50 \%$. Urbanization and urban sprawl affect almost all elements of the environment, with increased surface runoff being a notable effect among them (White and Greer, 2006; Sher Jamal Khan et al., 2011; Yang and Li, 2011). In recent decades, many studies have focused on the relationship between land use/cover changes and the quality and quantity of water supplies (see for example Carter et al., 2005; Bossio et al., 2010; Yang and Li, 2011). Many attempts have been made to establish relationships between surface runoff and such attributes as type, density, configuration, juxtaposition and polygonal shape of the land use/cover classes and their change over time. Well studied areas focus on such aspects as land use composition and water quality (Roberts and Prince, 2010), deforestation and runoff volume increase (Germer et al., 2010), land uses that increase rapid runoff(Weatherhead and Howden, 2009), land uses that protect against runoff (Blavet et al., 2009), effects of land use and climate change on surface runoff (Li et al., 2009) and watershed management scenarios towards reduced runoff (Alemayehu et al., 2009). Surface runoff has also been linked to urban sprawl (Arthur-Hartranft et al., 2003; Carlson, 2004; Su et al., 2010), and sprawl has been in turn modeled using different models such as the Land Transformation Model developed by Pijanowski et al (2000) (Tang et al., 2005), Clue-S developed by Verburg et al. (2002) (Dams et al., 2008) and SLEUTH developed by Clarke and Gaydos (1998) (Hosseinnia et al., 2009). Qi et al. (2008) proposed a model to optimize agricultural land use for lowering runoff, and Randhir et al. (2001) prioritized a watershed, incorporating relationships between land features and travel time of runoff. In all instances, the scientific literature indicates the feasibility of developing better land use patterns for minimizing runoff (Yeo et al., 2004; Poelmans et al. 2010).

In the present study, we investigate the possibility of informing the SLEUTH urban and land use/cover modeling method (Clarke and Gaydos, 1998) with urban land suitability and surface runoff layers. While the main function of the SLEUTH model is mimicking past land use/cover changes for the prediction of likely future scenarios, rather than optimizing patterns, nevertheless the model has the added capability of incorporating other input layers into its modeling process. It is in this context that we use SLEUTH in the current study to assess the effects and performance of adding an "Urban Suitability Layer" and a "Runoff Volume Layer" to the model. The aim is to assess the feasibility of forecasting the hydrologic impacts of land use/land cover growth and in changes in their patterns in order to suggest means for their improvement. We also seek to provide a context for incorporating the results in land use planning efforts and suggesting the means for amelioration of negative hydrologic impacts. Ideally, these informed management plans should help managers and decision makers in directing plans towards desired sustainable goals that approximate a favorable future condition.

\section{Materials and Methods}

\subsection{General Methodology}

\subsubsection{Study Area}

The area of study covers Gorgan and Ali-Abad townships in Iran, collectively named Gorgan Township for brevity. The area is approximately 98,000 hectares, located in the north east of Iran close to the south eastern coast of the Caspian Sea (Figure 1). The study area is part of Golestan Province and in the south is covered with lush Hyrcanian temperate forests; while in the north vast plains covered with farms and rangeland dominate the landscape. The Province is one of the major agricultural centers of Iran. Over the past few decades and following the designation of the area as a new province of the country, rapid population growth has occurred with accompanying unplanned sprawl of urban and industrial sites that demands sustainable development plans be designed and implemented to direct future changes. The area is currently suffering from a shortage of freshwater sources, especially during summer time.

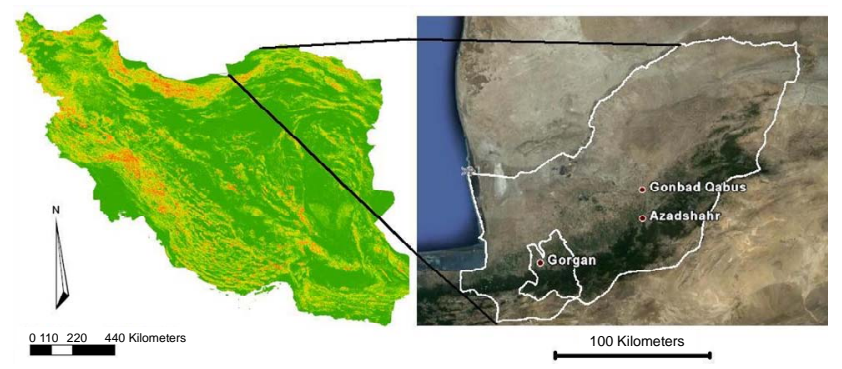

Figure 1. Iran (left), Golestan Province (right) and Gorgan Township as the study area inside the Province.

\subsubsection{Data Used for SLEUTH Modeling}

SLEUTH uses six input layers to model changes in urban areas and land cover types (Clarke and Gaydos, 1998). These include Slope, Land Use/Cover, Excluded layer, Urban areas, Transportation and Hillshading, hence the name. The last layer is used only for presentation purposes, while the other five operate together in the model to mimic past changes based on Markov and cellular automata methods to forecast possible futures for the land use and cover types. SLEUTH needs a layer in percent topographic slope, at least two land use maps, one excluded layer depicting areas which cannot be developed, at least four urban layers showing the expansion of urban land uses over a reasonable time span, and two layers exhibiting transport networks in two different time periods.

To run the model, one usually prepares the data required, verifies the model functions, calibrates the model, predicts the change and builds the forecast products. In running the model, five coefficients including diffusion, breed, spread, slope-resistance and road gravity are calculated that are governed by estimation of four growth rules consisting rules relating to sponta- 
neous growth, new spreading centre growth, edge growth and road-influenced growth. These are achieved in growth cycles each equal to one year or other appropriate time unit. The results are then passed through coarse, fine and final calibration modes during which the growth coefficients are refined, the final growth rules are set and a growth rate is calculated. The diffusion coefficient reflects the likelihood of dispersive growth, the breed coefficient shows the possibility of growth in detached areas, the spread coefficient represents the growth outwards of existing and consolidated urban areas, the road gravity coefficient denotes the influence on growth from the transportation network, and the slope resistance shows the influence of topographic slope on urbanization.

The slope layer was derived from the $30 \mathrm{~m}$ digital elevation model (DEM) of the area interpolated from VMAP1 data (www.mapability.com) and from ancillary information from the Iranian Cartographic Center, both at 1:50,000 scale. To prepare the land use/cover maps, we used Landsat TM and ETM+ imagery of the area for the years 1987, 1992, 2000 and 2005. A hybrid process including unsupervised, supervised and on-screen visual classification was undertaken (Lang et al., 2008). The road layer was prepared for all four dates using the available VMAP1 (www.mapability.com) layer plus on-scr een digitizing. Nine classes of land use/cover types were defined that included forest, rangeland, barren, urban, urban vegetation, agriculture, water bodies and rivers, road networks and remnant vegetation in the form of tree-covered but isolated patches. The excluded layer consisted of zones outside of the province, water bodies and road networks. The hill-shade was also prepared from the DEM using Idrisi Taiga (Eastman, 2009). The final image layers used in the process had 1,421 columns, 1,572 rows, and a $30 \times 30 \mathrm{~m}$ cell size.

\subsubsection{Data Used for Urbanization Suitability Assessment through MCE}

Landscape potential for and sensitivity to various land uses are known to be affected by a host of different environmental parameters. Hence, it has become normal practice to define and prepare maps of such environmental factors and combine them through a proper format. When this process is implemented digitally, it takes the name multi criteria evaluation (MCE). Normally, in the process of MCE, raster maps of the environmental parameters containing cells with different values are fuzzified using fuzzy set concepts (Zadeh, 1965). Through the fuzzification process, values are stretched using fuzzy membership curves. The process standardizes values in the layers, allows for the inclusion of uncertainty in the data layers and provides a means of conflating different opinions on the relative importance of each layer.

As environmental criteria affect the potential and sensitivity of the area unequally, they are usually assigned weights, normally through methods such as the analytical hierarchy process (AHP) developed by Saaty (1980) (Banai, 1993; Malczewski, 1999; Malczewski, 2006). In general, the method implements a comparison between every possible pair of criteria by means of an appreciation scale generally ranging between 1 and 9 in the form of a relative matrix (Svoray et al., 2005). A second group of digital map layers used in MCE are "constraints" that contain cells with values 0 and 1 showing unsuitability and suitability of developing the given land use, respectively. Generally, the fuzzified factor layers and the constraint layers are combined through such methods as weighted linear combination (WLC) and ordered weighted averaging (OWA). For a detailed treatment of the methods refer to the Idrisi software manual (Eastman, 2009).

We used 15 map layers in the MCE for Gorgan Township including elevation, slope, aspect, pedology, geology, forest density, land use/cover, underground water depth, climate classification, minimum and maximum temperature, proximity to: (a) rivers and water-bodies, (b) roads, (c) town edges, and distance to: (d) villages and industrial sites, (e) geological faults, and (f) protected areas. This decision was made based on Makhdoum (2007), data availability and a review of relevant literature for domestic and overseas issues (Austin, 2005; Al Shalabi et al., 2006; Lwasa, 2005; Roccasalva et al., 2007; Hossain et al., 2006; Naghibi and Shirmohammadi, 2008).

\subsubsection{Data Used for L-THIA Surface Runoff Modeling}

The Long Term Hydrologic Impact Assessment (L-THIA) method (Harbor, 1994; Engel, 2005) is a tool that provides estimates of changes in runoff, recharge and non-point source pollution resulting from past or proposed land use changes (Ma, 2004). L-THIA is based on the SCS runoff Curve Number $(\mathrm{CN})$ method and determines runoff from precipitation data, $\mathrm{CN}$ value, land use and soil layers. The runoff $\mathrm{CN}$ is based on the area's hydrologic soil group, land use and hydrologic condition. The basic assumption of the SCS CN method is that, for a single storm, the ratio of actual soil retention after runoff begins to the potential maximum retention is equal to the ratio of direct runoff to available rainfall. This relationship, after algebraic manipulation and inclusion of simplifying assumptions, results in Equation (1)(USDA-SCS, 1985), where CN represents a convenient representation of the potential maximum soil retention, S (Ponce and Hawkins, 1996):

$Q=\frac{(P-0.2 S)^{2}}{P+0.8 S}$

where $Q$ is runoff ([L]; in); $P$ is rainfall ([L]; in); $S$ is the potential maximum soil moisture retention after run- off begins ([L]; in).

The runoff curve number, $\mathrm{CN}$, is then related: $S=1,000 / \mathrm{CN}$ - 10 for water depths in inches and $S=25,400 / \mathrm{CN}-254$ for water depths in $\mathrm{mm}$. Lower $\mathrm{CN}$ numbers indicate low runoff potential while larger numbers are for increasing runoff potential.

L-THIA needs inputs of daily precipitation data for at least 30 years, a land use/cover map of the study area and a soil map. Daily precipitation data over 30 years between 1976 and 

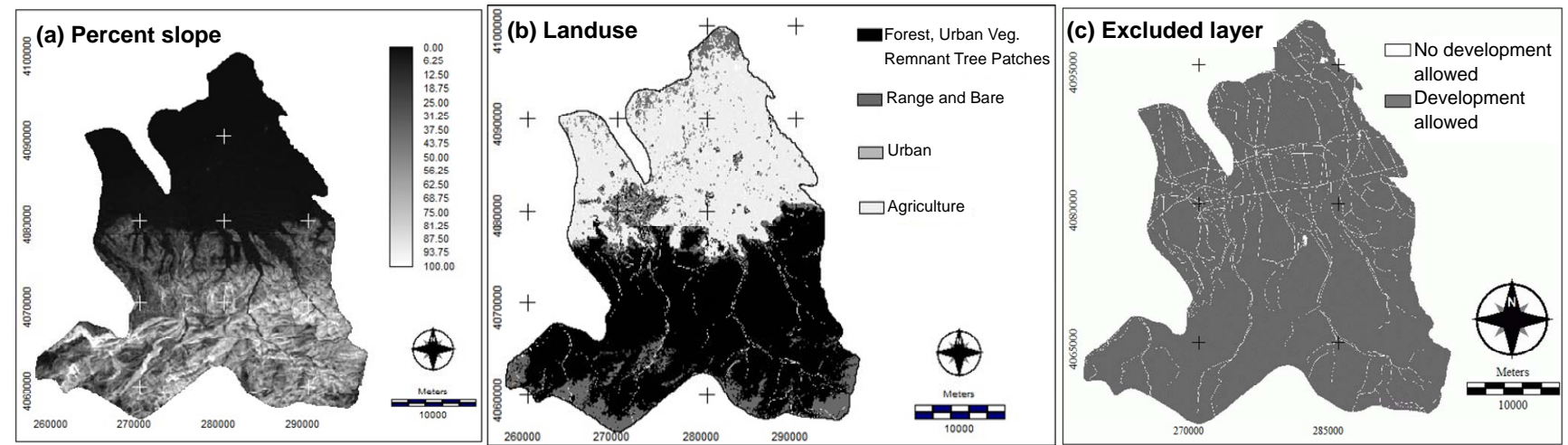

Figure 2. Percent slope (a), land use (b) and excluded layer (c) used in the SLEUTH modeling. For clarity, roads, rivers and water-bodies have been removed from the land use map. Also, forests, urban vegetation and remnant trees have all been shown with dark black and bare and rangelands shown in dark gray to give enough contrast for the urban areas to be distinguishable.
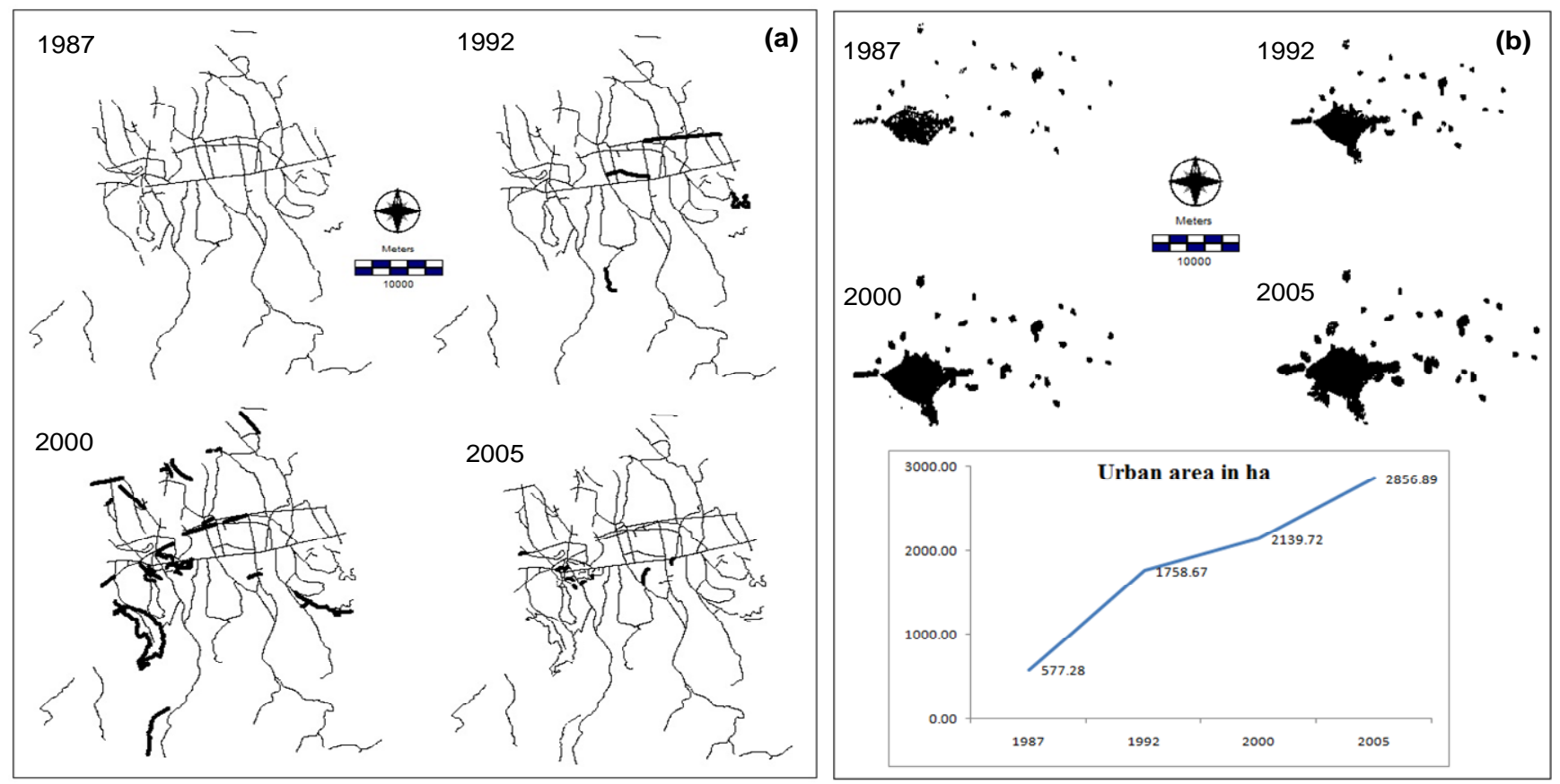

Figure 3. (a) Roads and their increase through time dark black lines); (b) urban areas and their expansion with their areal change.

2006 was acquired through the Iranian Meteorological Organization from the closest weather station in the north, $15 \mathrm{~km}$ from the area's center. For the land use map, we employed the classified Landsat-based land use/cover map for 2005, the predicted map for 2040 through the original SLEUTH application, the MCE-informed SLEUTH application, the hydrologic-MCE informed SLEUTH application, and that of the simple MCE for 2040. The same soil map used in the MCE for urbanization suitability was also used for L-THIA.

\subsection{Setting up the Case Study Models}

\subsubsection{SLEUTH Modeling}

The slope layer and land use/cover types for the years
1987, 1992, 2000 and 2005 were used in SLEUTH and roads, rivers and pixels outside the study area were excluded from urban development. We also assigned a value above 100 to prevent the model entirely from urbanizing the excluded areas (Figure 2).

Figure 2 shows the slope in percent, the excluded layer and for brevity, only the 1987 land use map is shown. Figure 3 shows the road networks and the urbanized area for different years.

The layers were used in the three automated calibration phases of SLEUTH: coarse, fine and final. SLEUTH uses four urban growth rules in an iterative Monte Carlo approach and brute force calibration methods to arrive at five coefficients 
that define urban growth based on given inputs for slope, two land use maps, one excluded layer, four urban extent maps and, in this case, four road layers. These coefficients are: diffusion, breed, spread, and slope and road gravity. While there are various aspects of modeling accuracy that are relevant in terms of the scale, the dynamics of the landscape, the approach towards modeling change and the amount of observed change (Pontius et al., 2008), recently a combination of a subset of 7 measures of goodness of fit has been proposed for assessing accuracy of SLEUTH prediction. These include compare, population, edge, clusters, slope, xmean, and ymean metrics all produced during SLEUTH application (Dietzel and Clarke, 2007). The seven metrics, all in the range $0.0 \sim 1.0$, are multiplied together to give the Optimized Sleuth Metric (OSM), the higher the OSM, the higher the fit of the modeling. In the process, the model's measures of goodness of fit are compared to the real land use maps in the final calibration year, so the OSM metric reflects conformity with the known situation on the ground. The calibration process and model behavior are described fully in Silva and Clarke (2002).

The final coefficients were set at 34, 24, 56, 1 and 48 for diffusion, breed, spread, and slope and road gravity, respectively. These values were used to predict urban and land cover changes up to the year 2040 in SLEUTH's prediction mode.

\subsubsection{Urban Suitability Modeling}

While there are no universal threshold values for standardizing factors, common ecological, social and economic understanding can be used as first shot attempts in this regard. There are documents such as that of Makhdoum (2007) for Iran and others for other countries which can be useful for defining suitable thresholds of factors. Our implementation reflects ideas based on expert knowledge and the available documents. However, these values can be easily changed in any multi-criteria evaluation (MCE) and the process repeated in virtually no time until consensus is achieved. In doing so, however, the ecological boundaries, namely the acceptable limits of change should be respected and observed.

For the MCE, slopes above $20 \%$ were restrained from development (Makhdoum, 2007; Naghibi and Shirmohammadi, 2008; Al Shalabi et al., 2006) and those between 0 and 20\% were linearly fuzzified using a monotonically decreasing trend in the range $0 \sim 1$. As the area is relatively warm in summers, eastern and western aspects were given priority in the userdefined process of fuzzification. The north facing areas ranked next, while the south facing slopes were given the lowest fuzzy value. Flat areas were given the highest fuzzy value (most suitable) of 1 .

For soil properties, we used the land capability layer at the scale of 1:250,000 provided by the Iran Soil and Water Research Institute and assigned fuzzy values using the standard land use planning procedure in Iran (Makhdoum, 2007). The geology layer was also available through the National Geodetic Database of Iran (NGDIR) at the scale of 1:250 000 for which the suitability of different rock formations in the area were defined (Makhdoum, 2007; Doygun et al., 2008). Distances to ri- vers and water-bodies were fuzzified through the linear symmetrical function in which distances of $0 \sim 200 \mathrm{~m}$ were assigned zero and defined as a buffer to protect water resources and prevent damage to settlements from flooding. Then, the suitability increased linearly up to $1,000 \mathrm{~m}$, stayed the same up to 3,000 $\mathrm{m}$ and decreased afterwards.

To allocate enough land for future road development and enhancement, and to provide suitable areas for urbanization, a distance of $200 \mathrm{~m}$ was set aside and cells farther than that were assigned linearly decreasing fuzzy values (Al Shalabi et al., 2006). The buffer for roads inside towns was set at $60 \mathrm{~m}$. Also, to encourage clumped and centralized urban growth, a distance map was generated from the current urban areas and fuzzified through a linear monotonically decreasing function. Using the classified land use/cover map of the area for 2005, we defined fuzzy values for the nine land use categories through a userdefined option. Also, a distance up to 3,000 $\mathrm{m}$ from fault lines was assigned value 0 and distances further than that were given fuzzy values using a linear monotonically increasing function (Kerr et al., 2003; Lotfi et al., 2011; Tudes, 2012). The normalized difference vegetation index (NDVI) was calculated using bands 3 and 4 of the Landsat ETM+ imagery and fuzzified such that values greater than 0.25 were assigned 0 , protecting the healthiest vegetation (Mohammadi and Shataee, 2010). In the range $0 \sim 0.25$, the higher the NDVI value, the less the fuzzy value using a linear monotonically decreasing function.

A buffer of 1,000 m was used for the Jahannama Protected area and further than that a linear monotonically increasing function was used to fuzzify the layer and encourage urban development away from the protected area. The protected area itself was assigned a value 0 and considered a full constraint to development. A minimum distance of $210 \mathrm{~m}$ was considered as buffer for the villages and areas further than that were fuzzified using the linear monotonically decreasing function to encourage less dispersed growth through forcing aggregation around existing settlements.

De Martonne climatic classification was applied for the area using WorldClim data (Hijmans et al., 2006). To encourage urban growth in the middle altitudes --- where daily and nightly winds through the valley bottom can ventilate the city --- a linear symmetrical fuzzy function was used for elevation layer.

We used the analytical hierarchy process (AHP) for weighting the factors based on experience and general knowledge of the area. However, the flexibility of digital MCE allows repetition as many times as is desired within the acceptable ecological standards for the range of layer values until consensus is achieved among stakeholders. For instance, the highest acceptable slope for urban development in Iran is around 20\% (Makhdoum, 2007). However, decision makers and stakeholders may be ready to accept higher risks or expenses and set the slope slightly higher. The same applies to other factors as well. The measured consistency ratio of the AHP weighting was 0.09 , within the acceptable limit and a weighted linear combination was applied using Equation (2):

$M C E_{\text {UrbanSustainability }}=\sum_{i=1}^{n} w_{i} x_{i} \times \Pi C_{i}$ 
In Equation (2), $w_{i}$ is the weight of factor $i, x_{i}$ is the fuzzified factor $i, \Pi$ is the multiplication operator and $C_{i}$ is constraint $i$. The result of the MCE is a single layer with cell values in the range $0 \sim 1$ or $0 \sim 255$ based on the fuzzification range. The higher the value, the higher is the suitability for urbanization. For the MCE results the zonal land suitability (ZLS) method (Eastman, 2009) was used with a suitability threshold of 95/100 and a minimum size of 5 hectares was applied.

\subsubsection{Runoff Depth and Volume Modeling}

To calculate runoff depth and volume, the L-THIA extension version 2.3 for Arcview 3.3 was used. The required table for land use/cover types and soil types was prepared using information on "Urban Hydrology for Small Watersheds" (USDA, 1986). Although the extension currently accepts a set of eight land use/cover classes with predefined names, nonetheless it is still possible to include other classes as long as the naming convention is observed (Table 1).

Table 1. Codes and Curve Numbers for the Land Use/Cover Types in Association with the Soil Types in the Study Area for the L-THIA Modeling*

\begin{tabular}{llllll}
\hline & \multicolumn{5}{c}{ Soil Hydrologic Groups } \\
\hline Land Use/Cover & $\begin{array}{l}\text { Land Use/Cover } \\
\text { Code }\end{array}$ & $\mathrm{A}$ & $\mathrm{B}$ & $\mathrm{C}$ & $\mathrm{D}$ \\
& \multicolumn{5}{c}{ Curve Number } \\
Forest & 7000 & 30 & 55 & 70 & 77 \\
Rangeland & 6000 & 49 & 69 & 79 & 84 \\
Barren & 5000 & 77 & 86 & 91 & 94 \\
Urban & 4000 & 80 & 88 & 91 & 93 \\
Urban Greenery & 2000 & 46 & 67 & 77 & 83 \\
Agriculture & 3000 & 70 & 80 & 83 & 90 \\
Water & 1000 & 0 & 0 & 0 & 0 \\
Roads & 8000 & 98 & 98 & 98 & 98 \\
Remnant & 2000 & 46 & 67 & 77 & 83 \\
Vegetation & & & & & \\
\hline Source: Urban Hydrology for Small Watersheds (USDA, 1986)
\end{tabular}

Basically, we used the precipitation data along with the content of Table 1 for each run of L-THIA in which only the land use/cover map changed. The soil map was the same and the number of urban cells remained equal for all runs. However, the location and size of the land use/cover types differed among the four implementations of the L-THIA. A land use/cover map of the year 2005 classified from the Landsat ETM+ imagery was used as the basis for comparisons among the different scenarios of land use/cover patterns for 2040 .

\subsubsection{Adding MCE Result to SLEUTH}

Values in the MCE layer for urban suitability assessment were inverted such that the highest suitability in the layer had the lowest value in the excluded layer, as SLEUTH requires. In this way, those areas most suitable for urbanization had the lowest resistance to urbanization in the excluded layer and vice versa. The areas absolutely unsuitable for urbanization were given the value 255 to introduce total resistance to urbanization.

Using the same average values arrived at the last SLEUTH calibration step, the new excluded layer was introduced to forecast urban expansion up to the year 2040 .

\subsubsection{Adding MCE and L-THIA Results to SLEUTH}

The estimated runoff volume layer for the base year 2005 was used such that the higher the possibility of runoff volume, the higher the resistance to urbanization.

The MCE layer for urban suitability was combined with the reclassified runoff volume layer and incorporated into the "Excluded Layer" of SLEUTH. Subsequently, using the same average values arrived at the last calibration step, the new excluded layer was introduced to the forecasting process of SLEUTH to forecast urban expansion up to the year 2040.

\subsubsection{Assessment of Runoff Volume and Landscape Metrics}

For runoff volume estimations, we used the likely land use/cover pattern maps of the year 2040 provided through: (1) original SLEUTH modeling, (2) Simple MCE for urban suitability, (3) MCE informed SLEUTH modeling and (4) hydrologic-MCE informed SLEUTH modeling.

The same number of cells predicted to urbanize up to the year 2040 in the original SLEUTH run was used in other modeling efforts. To also assess the effects of different approaches on the configuration and juxtaposition of different land use/cover types taken as indicators of optimized landscape pattern, we calculated selected landscape metrics using Fragstats software version 3.3 (McGarigal and Marks, 1995). The metrics included number of patches, patch density, largest patch index, landscape shape index, mean perimeter to area ratio and mean Euclidean distance of the patches. These were chosen based on the ease of their interpretation, their relevance and frequency of use in the literature (Bruce Jones et al., 2000; Hernandez et al., 2003; Li et al., 2005; Richert et al., 2007; Bianchin et al., 2011).

\section{Results and Discussion}

Final averaging values for the five growth coefficients diffusion, breed, spread, slope and road gravity were arrived at $29,20,47,2$, and 47 respectively. These values show the higher importance of spread, and road gravity on city growth, less effect of diffusion and breed and very small relationship between slope and city sprawl in the area. In the five best performing iterations, the lowest goodness of fit metrics at the final calibration step were 0.98 for compare, 0.94 for pop, 0.99 for edge, 0.67 for clusters, 0.79 for slope, 0.99 for xmean and 0.63 for ymean, all favorable. The OSM metric; which is a summation of the comparison of predicted versus observed land use/cover pattern was on average 0.35 which is favorable. For an explanation of these metrics, the readers are referred to the Gigalopolis Website.

Prediction of land use/cover with the original excluded layer resulted in a "Cumulate_Urban" layer that allowed urbani- 
zation throughout the area with the exception of dense forests (Figure 4). The "Cumulate_Urban" layer shows the Monte Carlo-derived probability of urbanization for each pixel in the range $0 \sim 100$ with the higher values indicating higher frequency and so probability of urbanization by 2040 .

Figure 4 shows that the highly probable pixels for urbanization are located surrounding the existing urban areas. We found that nearly all the cells within the urban areas are prone to urbanization by removal of urban green spaces as is the case with the remnant vegetation. Infill happens to urban areas such that with the exception of excluded roads, most other open locations within the cities and towns are developed through time.

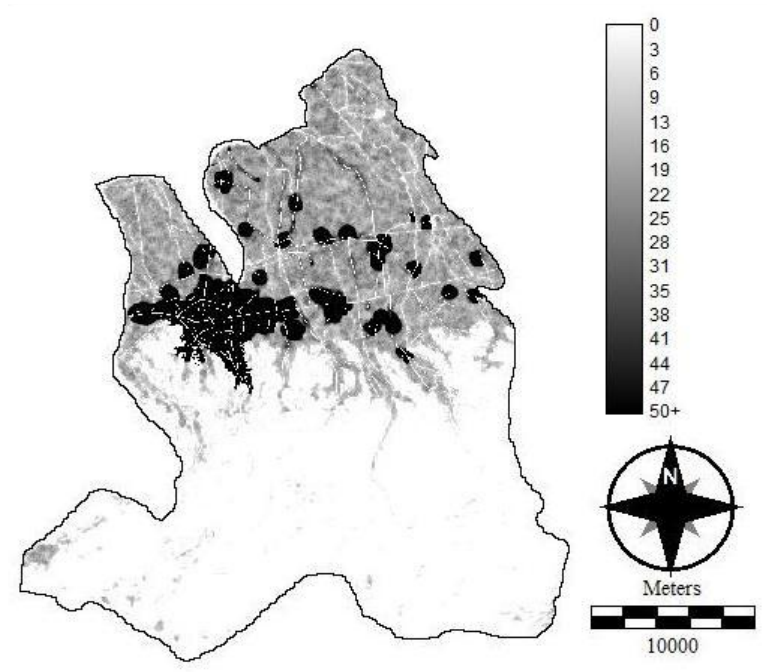

Figure 4. The probability of urbanization in the study area using the original excluded layer. The higher the value (shown as darker), the greater is the probability.

The target prediction year was set at 2040 in which the probable urban expansion depicts a very scattered and disaggre- gated pattern. As expected, the model's response to more restrictions results in a more organized pattern of urbanization. When the hydrology and MCE constraints were combined, the model prevented urban growth in the south of the area, close to high density forest, fault lines, protected areas and on steep slopes (Figure 5).

Additionally, a closer inspection of the resultant urban development patterns revealed that urban green spaces are better conserved through inclusion of the urban suitability map into the future development forecast. The same is true for the hydrologic-MCE informed SLEUTH modeling.

Original urban forecast through SLEUTH showed a probability of urbanization for around 2,630 hectares of land by the year 2040 based on the $100 \%$ probability cut-off point (the most conservative estimate). For the MCE excluded layer, this was 1,164 hectares. For the simple MCE the highly suitable sites were chosen through ZLS such that 1,900 ha of new urban pixels (the average of the other two methods) was achieved (Figure 6). In the figure, the 20 best ranking polygons adding up to the required area were selected and shown.

The clumped groups of cells in Figure 6 provide a summation of the suitability for urbanization, in the absence of interaction among the different land use/cover types. However, this result lacks information on urban development in the outskirts of towns and their periphery, proximity to town centers and other factors that are important in achieving organic growth.

When the urban suitability MCE layer and that of the hydrology-MCE are incorporated into the process, a somewhat different pattern is generated (Figure 7). When the two latter layers are used in the SLEUTH predictions, the land use/cover change simulation is informed with the five growth coefficients of SLEUTH, fifteen layers used in the MCE process and also information on curve number of soils and land use applied through the hydrology layer. The aggregate change is realized through interaction of all these information sources.

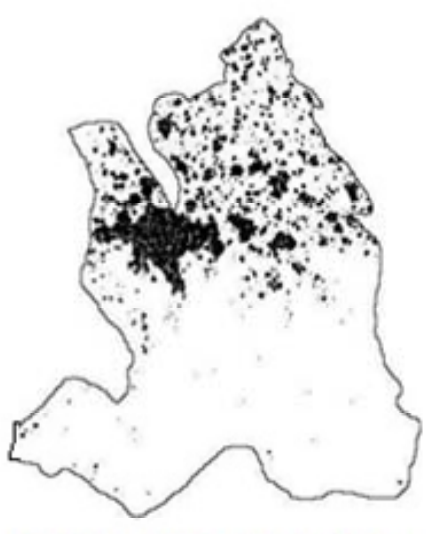

Original excluded layer

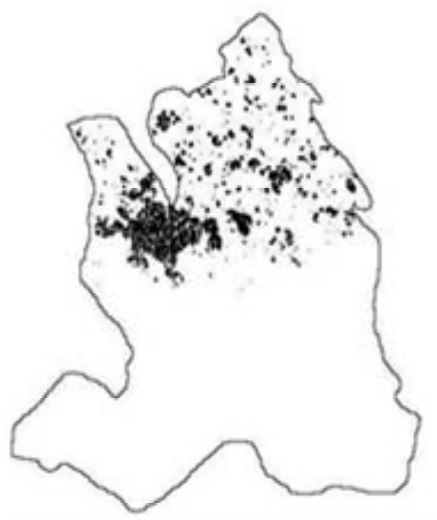

MCE excluded layer

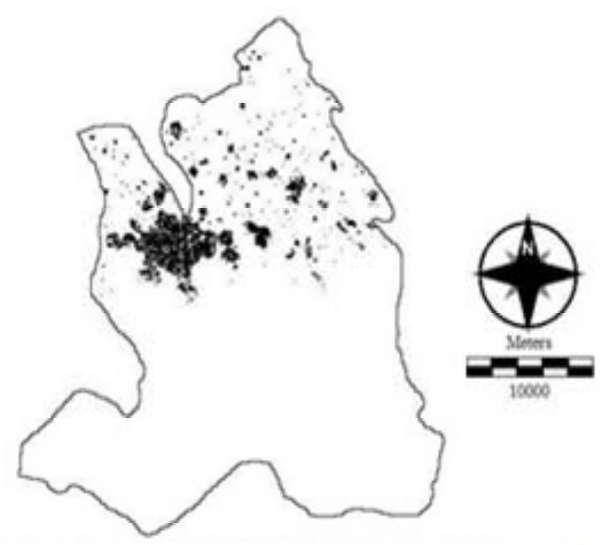

Hydrology-MCE excluded layer

Figure 5. Predicted urban pattern for the year 2040 using the whole range of cut-off probability values on the original, MCE excluded and hydrologic-MCE excluded layers. 


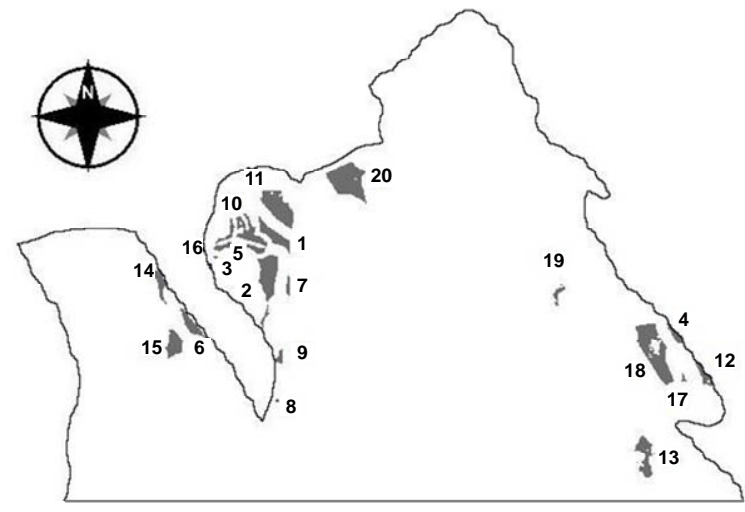

Figure 6. New urban development areas selected through ZLS. Figures indicate rank of the polygons for development.

Most of the new forecast urban cells are located in the periphery of the existing developed areas (Figure 7). This reflects the effect of the diffusion, breed and spread coefficient values. Generally, the location of changes looks somewhat similar with the exception of the fact that in the model growth design, change in land use/cover and the desired pattern of change are also taken into account.

We used the final 2040 urban MCE model, the original SLEUTH, MCE informed and hydrologic-MCE informed SLEUTH runs in runoff volume estimations by L-THIA. Figure 8 shows runoff volume for the category urban and the whole area. We also used runoff depth and volume estimated for the land use/cover map of the base year 2005 for comparison.

With the same number of urban cells, more suitable spots in terms of urban suitability and runoff volume have been highlighted in the informed modeling (Figure 8). As for the magnitude of the hydrologic effects, the same trend is seen when comparing results with that of the year 2005 .

We realize that in both cases of urban development using simple MCE and the original SLEUTH, the estimated runoff volume is always higher than the informed cases of SLEUTH implementation (Figure 8). However, the estimate of total runoff for the hydrologic-MCE informed SLEUTH is slightly less

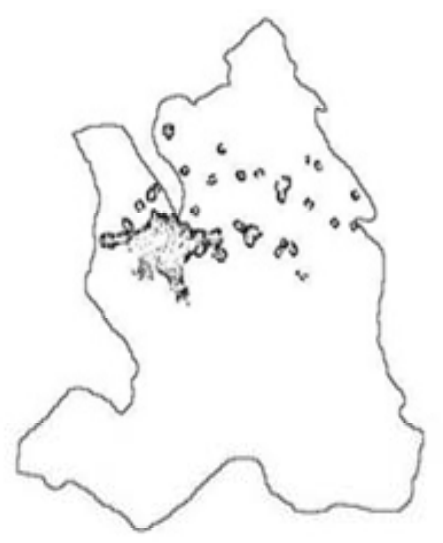

Original excluded layer

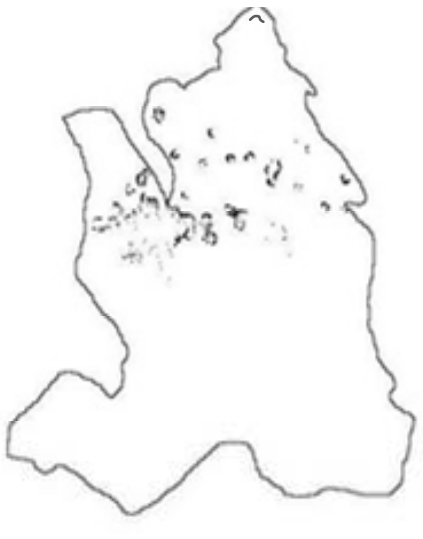

MCE excluded layer

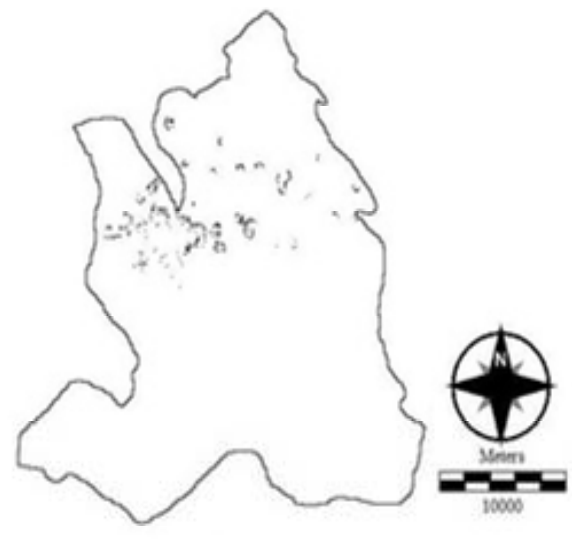

Hydrology-MCE excluded layer

Figure 7. New urban development areas defined through SLEUTH modeling using 100\% cut-off probability on the original excluded layer (left) and MCE excluded layer (right).

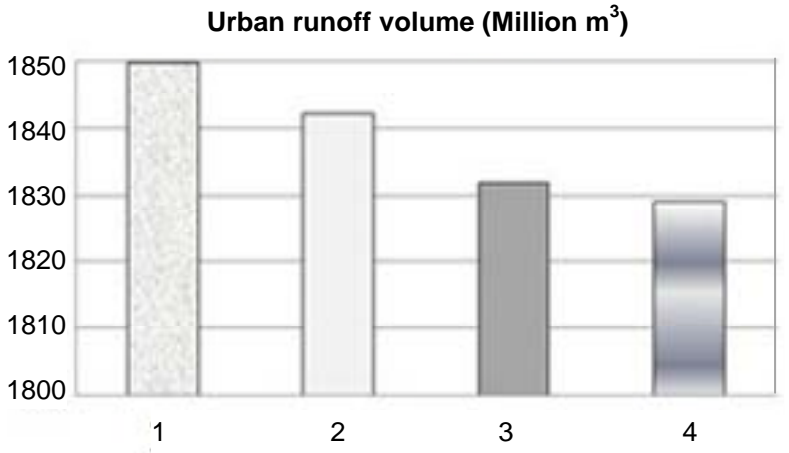

1 Only MCE

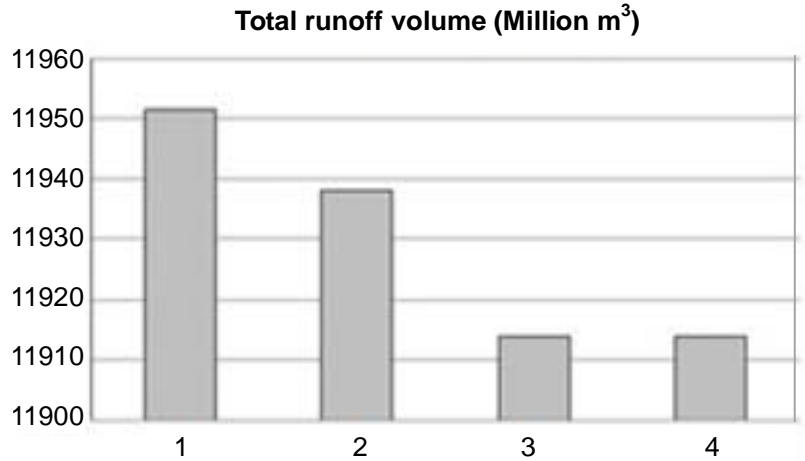

3 MCE SLEUTH

4 Hydrology-MCE SLEUTH

Figure 8. Urban and total runoff volume estimation by L-THIA for the four modeling applications. 
than that of the MCE informed SLEUTH applications (Figure $8)$. The reason for this is that in the hydrologic-MCE informed SLEUTH application; more suitable pixels are allocated to the urban category and in doing so other categories are pushed towards slightly less suitable locations.

SLEUTH also produces an uncertainty layer for each prediction showing the Monte Carlo derived deviation from reality of suggested pixels for urban and land cover change. The uncertainty layer generated during SLEUTH application contained lower average uncertainty for the informed modeling approaches compared with that of the original (Table 2). We note that the hydrologic-MCE informed modeling improved the reliability of the results in terms of urban allocation.

Table 2. Percent Uncertainty Associated with Predictions in Three SLEUTH Model Runs

\begin{tabular}{llll}
\hline & Maximum & Average & SD \\
\hline Original SLEUTH & 60 & 10.8 & 11.5 \\
MCE_SLEUTH & 53 & 6.2 & 9.6 \\
Hydrologic_MCE_SLEUTH & 51 & 3.5 & 8.4 \\
\hline
\end{tabular}

Inclusion of the hydrology-MCE layers in the excluded layer of SLEUTH has helped to lower the likely amount of surface runoff generation compared with the other scenarios (Figure 8). Landscape metrics calculated using Fragstats software version 3.3 (McGarigal and Marks, 1995) are shown in Table 3.

The number of patches (NP), patch density (PD), the largest patch index (LPI), landscape shape index (LSI), and the mean area are generally more desirable from a sprawl perspective for the informed SLEUTH applications (Table 3). This is also the case with perimeter to area(PARA) ratio and the mean Euclidean nearest neighbor ( $\mathrm{MNN})$.

At the landscape scale, the results of hydrologic-MCE informed modeling are generally more favorable than those of the two other modeling efforts in terms of landscape metrics. In all, the hydrologic-MCE informed SLEUTH modeling shows more desirable results when compared to the other two app- roaches in terms of runoff volume, landscape metrics and land suitability for urban development.

\section{Conclusions}

Three approaches of simulating and predicting land use/cover type location and quantity in Gorgan Township using the SLEUTH model and a simple MCE for urban suitability were compared in terms of surface runoff volume and landscape metrics of the forecast patterns in 2040. We have shown that SLEUTH model is able to absorb other information layers into its "Excluded Layer" such that the new information is represented in the growth coefficients. SLEUTH can also be regarded as a self-organizing approach to land use/cover change modeling. This aspect of SLEUTH has not yet been explored extensively and merits more attention. We showed that the SLEUTH model informed with urban suitability and hydrology layers produces maps of future land use/cover patterns that are more favorable than those of the MCEinformed and original SLEUTH in terms of runoff volume and land suitability. The findings indicate that with the extra information in the "Excluded Layer" of SLEUTH, an enhanced land use/cover plan is produced with regards to urban suitability and runoff reduction, while landscape metrics of the land use/cover types are improved at the same time.

The balancing of weights when combining the two extra layers of MCE for urban suitability and runoff volume needs more investigation. We applied an equal weight when combining MCE and hydrology layers, but the total runoff volume could have been less for the hydrologic-MCE informed SLEU$\mathrm{TH}$ had we assigned a smaller weight to the urban suitability and a higher weight to the hydrology layer. Of course, this is a matter of balancing between different objectives and could be the subject of further investigation. With an increase in the included layers, the dimensionality of the input layers increases and this may alter the behavior of SLEUTH and warrants further research. Just to what extent is it possible to include extra layers in the "Excluded Layer" for achieving a more comprehensive land use plan is a topic of future studies. At

Table 3. Landscape Metrics for Predicted Land Use/Cover of the Year 2040 Using the Original, MCE Informed and Hydrologic-MCE Informed Excluded Layers

\begin{tabular}{|c|c|c|c|c|c|c|}
\hline Metrics & $\mathrm{NP}$ & PD & LPI & LSI & PARA_MN & ENN_MN \\
\hline Original & 9079 & 4.51 & 22.45 & 36.01 & 1045.35 & 158.38 \\
\hline MCE & 8915 & 4.43 & 22.66 & 34.46 & 1034.226 & 140.21 \\
\hline Hydrologic_MCE & 8572 & 4.26 & 22.70 & 33.04 & 1025.61 & 139.67 \\
\hline
\end{tabular}

*NP $=$ Number of patches. Normally the lesser the number the more integrated the landscape, which is favorable.

$\mathrm{PD}=$ Patch density. Number of patches per area. The lesser the patch density, the more clumped and intact the landscape is.

LPI $=$ Largest patch index. A measure of the size of the patches and the larger the figure the less fragmented the landscape, which is favorable.

LSI = Landscape shape index. LSI equals the total length of edge (or perimeter) involving the corresponding class, given in number of cell surfaces, divided by the minimum length of class edge (or perimeter) possible for a maximally aggregated class, which is achieved when the class is maximally clumped into a single, compact patch. LSI = 1 when the landscape consists of a single square or maximally compact (i.e., almost square) patch of the corresponding type; LSI increases without limit as the patch type becomes more disaggregated (i.e., the length of edge within the landscape of the corresponding patch type increases) (McGarigal and Marks, 2005).

PARA_MN = Mean perimeter to area ratio of the patches. The less the figures the more circular the patches are, hence the less edge and vulnerability to human encroachment and diseases.

ENN_MN: Mean nearest neighbor. The closer the patches, the less fragmented they are which is favorable. 
some point, these factors would be better simply incorporated into the land use change model itself.

Others have attempted coupled land use change and hydrologic modeling. Poelmans et al. (2010) showed that the pattern of land use affects the hydrologic properties of the landscape. Yeo et al. (2004) linked a peak runoff flow model at the outlet and a cell-based land use model to optimization the pattern of land use/cover and runoff. Carter et al. (2005) illustrated a method by which land use planning and water management activities could be evaluated through the development of a normative model applied to three study municipalities in the Province of Ontario, Canada. Chen et al. (2009) linked the HEC-HMS rainfall-runoff model to CLUE_S model of land use/cover change to quantify the impact of potential land use change on storm-runoff generation.

In the current study, we have taken a simple approach by using the L-THIA model without any change in its algorithms. However, even with this approach we have provided results indicating improvement of the final land use/cover maps in terms of surface runoff. Urban suitability and landscape metrics have also been improved with inclusion of the extra information layers. In this way, we have achieved a land use/ change model guided towards less runoff production, better landscape metrics and more suitable sites for urban development. Hence, in this regard, the approach is a combination of future change modeling with land use/cover planning which gives the latter a sense of dynamism. Linking SLEUTH with other pixel-wise methods of surface runoff calculations is deemed worthy of further investigation.

With the rapid decline in both quality and quantity of freshwater resources all over the world, it is now incumbent upon land use planners and decision makers to take preventive and restorative measures. Part of the information for such measures can be derived from the careful application of modeling approaches which predict the likely future condi- tions. SLEUTH is capable of providing such predictions while simultaneously approaching favorable plans with regards to the information layers introduced to the model. Land use planning approaches currently undertaken in Iran are mostly static and comprise hand or machine overlays of some relevant maps. However, in today's fast changing world with many stakeholders involved and less and less resources available, we need iterative methods enabling the relevant people and agents to take part in the process of planning and final decision making. The present study has provided a means through which decision makers and stakeholders in the Province can apply various growth and change scenarios in SLEUTH and also modify factor fuzzification curves for MCE and agree on a suitable development plan based on surface runoff, land suitability and land use/cover configuration. Provincial authorities who normally decide on the future of the province in Iran and their success rely heavily on the consensus of the stakeholders will hopefully benefit from this approach.

\section{References}

Alemayehu, F., Taha, N., Nyssen, J., Girma, A., Zenebe, A., Behailu,
M., Deckers, S., and Poesen, J. (2009). The impacts of watershed management on land use and land cover dynamics in Eastern Tigray (Ethiopia). Resour. Conserv. Recycling, 53(4), 192-198. http://dx.doi.org/10.1016/j.resconrec.2008.11.007

Al Shalabi, M.A., Mansor, S.B., Bin Ahmed, N., and Shiriff, R. (2006). GIS Based Multicriteria Approaches to Housing Site Suitability Assessment. XXIII FIG Congress Munich, Germany, October 8-13. 1-17.

Austin, L.M. (2005). Human settlement planning and design, Volume 1. CSIR Building and Construction Technology, Capture Press, Pretoria.

Banai, R. (1993). Fuzziness in geographical information systems: contributions from the analytic hierarchy process. Int. J. Geogr. Inf Syst., 7(4), 315-329. http://dx.doi.org/10.1080/0269379930890196

Bianchin, S., Richert, E., Heilmeier, H., Merta, M., and Seidler, Ch. (2011). Landscape metrics as a tool for evaluating scenarios for flood prevention and nature conservation. Landscape, 25, 1-11.

Blavet, D., De Noni, G., Le Bissonnais, Y., Leonard, M., Maillo, L., Laurent, J.Y., Asseline, J., Leprun, J.C., Arshad, M.A., and Roose, E. (2009). Effect of land use and management on the early stages of soil water erosion in French Mediterranean vineyards. Soil Tillage Res., 106(1), 124-136. http://dx.doi.org/10.1016/j.still.2009. 04.010

Bossio, D., Geheb, K., and Critchley, W. (2010). Managing water by managing land: Addressing land degradation to improve water productivity and rural livelihoods. Agric. Water Manage., 97(4), 536-542. http://dx.doi.org/10.1016/j.agwat.2008.12.001

Bruce Jones, K., Heggem, D.T., Wade, T.G., Neale, A.C., Ebert, D.W., Nash, M.S., Mehaffey, M.H., Hermann, K.A., Selle A.R., and Augustine, S. (2000). Assessing landscape condition relative to water resources in the Western United States: A strategic approach. Environ. Monit. Assess., 64(1), 227-245. http://dx.doi.or g/10.1023 /A: 1006448400047

Cao, W., Bowden, W.B., Davie, T., and Fenemor, A. (2009). Modelling impacts of land cover change on critical water resources in the Motueka River Catchment, New Zealand. Water Resour. Manage., 23(1), 137-151. http://dx.doi.org/10.1007/s11269 $-008-9268-2$

Carlson, T.N. (2004). Analysis and prediction of surface runoff in an urbanizing watershed using satellite imagery. J. Am. Water Resour. Assoc., 40(4), 1087-1098. http://dx.doi.org/10.1111/j.1752-1688.20 04.tb01069.x

Carter, N., Kreutzwiser, R.D., and de Loe, R.C. (2005). Closing the circle: linking land use planning and water management at the local level. Land Use Policy, 22(2), 115-127. http://dx.doi.org/10.1 016/j.landusepol.2004.01.004

Chen, Y., Xu, Y., and Yin, Y. (2009). Impacts of land use change scenarios on storm-runoff generation in Xitiaoxi basin, China. Quat. Int., 208(1-2), 121-128. http://dx.doi.org/10.1016/j.quaint.20 08.07.019

Clarke, K.C., and Gaydos, L. (1998). Loose-coupling a cellular automaton model and GIS: Long-term urban growth prediction for San Francisco and Washington/Baltimore. Int. J. Geogr. Inf. Sci., 12, 699-714. http://dx.doi.org/10.1080/136588198241617

Dams, J., Woldeamlak, S.T., and Batelaan, O. (2008). Predicting land use change and its impacts on the groundwater system of the Kleine Nete catchment, Belgium. Hydrol. Earth Syst. Sci., 12, 1369-1385. http://dx.doi.org/10.5194/hess-12-1369-2008

Dietzel, C., and Clarke, K.C. (2007). Toward optimal calibration of the SLEUTH land use change model. Trans. GIS, 11(1), 29-45. http://dx.doi.org/10.1111/j.1467-9671.2007.01031.x

Doygun, H., Alphan, H., and Kusat Gurun, D. (2008). Analysing urban expansion and land use suitability for the city of Kahra- 
manmaras, Turkey, and its surrounding region. Environ. Monit. Assess., 145(1-3), 387-395. http://dx.doi.org/10.1007/s10661-0070047-y

Eastman, J.R. (2009). Idrisi Taiga Version 16.01. Clark Labs, Clark University, USA.

Engel, B. (2005). L-THIA NPS, 46p. (http://www.ecn.purdue.edu/run off, Accessed 10 July 2010).

Germer, S., Neill, C., Krusche, A.V., and Elsenbeer, H. (2010). Influence of land-use change on near-surface hydrologic processes: Undisturbed forest to pasture. J. Hydrol., 380(3-4), 473-480. http:// dx.doi.org/10.1016/j.jhydrol.2009.11.022

Gleick, P.H. (1996). Water resources. In Encyclopedia of Climate and Weather, ed. by S. H. Schneider, Oxford University Press, New York, 2, 817-823.

Gleick, P. (2000). The World's water. Island Press.

Gleick, P.H., Singh, A., and Shi, H. (2001). Emerging Threats to the World's Freshwater Resources. A Report of the Pacific Institute for Studies in Development, Environment, and Security, Oakland, California, $64 \mathrm{pp}$.

Harbor, J. (1994). A practical method for estimating the impact of land use change on surface runoff, groundwater recharge and wetland hydrology. J. Am. Plann. Assoc., 60, 91-104. http://dx.doi. org/10.1080/01944369408975555

Hernandez, M., Kepner, W.G., Semmens, D.J., Ebert, D.W., Goodrich, D.C., and Miller, S.N. (2003). Integrating a Landscape/Hydrologic Analysis for Watershed Assessment. The First Interagency Conference on Research in the Watersheds, 27-30 October, Benson, AZ.1-6.

Hijmans, R.J., Cameron, S.E., Parra, J.L., Jones, P.G., and Jarvis, A. (2006). WorldClim (http://www.worldclim.org/), accessed June 2010.

Hossain, H., Sposito, V., and Evans, C. (2006). Sustainable land resource assessment in regional and urban systems. Appl. GIS, 2(3), 1-21. http://dx.doi.org/10.2104/ag060024

Hosseinnia, A., Salman Mahiny, A., and Tavassoli, A. (2009). An investigation on the relationship between urban growth in Chalus and Nowshahr and surface water runoff. Third Regional Conference of Agriculture and Natural Resources. Kurdistan University, Iran.

Kerr, J., Nathan, S., Dissen, R.V., Webb, P., Brunsdon, D., and King, A. (2003). A guideline to assist resource management planners in New Zealand. Ministry for the Environment, Wellington, New Zealand. $71 \mathrm{pp}$.

Lang, R., Shao, G., Pijanowski, B.C., and Farnsworth, R.L. (2008). Optimizing unsupervised classifications of remotely sensed imagery with a data-assisted labeling approach. Comput. Geosci., 34(12), 1877-1885. http://dx.doi.org/10.1016/j.cageo.2007.10.011

Li, Z., Liu, W., Zhang, X., and Zheng, F.L. (2009). Impacts of land use change and climate variability on hydrology in an agricultural catchment on the Loess Plateau of China. J. Hydrol., 377(1-2), 3542. http://dx.doi.org/10.1016/j.jhydrol.2009.08.007

Li, X., He, H.S., Bu, R., Wen, Q., Chang, Y., Hu, Y., and Li, Y. (20 05). The adequacy of different landscape metrics for various landscape patterns. Pattern recognition, 38, 2626-2638. http://dx.doi. org/10.1016/j.patcog.2005.05.009

Lwasa, S. (2005). A Geo-Information Approach for Urban Land Use Planning in Kampala. From Pharaohs to Geoinformatics, FIG Working Week 2005 and GSDI-8, Cairo, Egypt April 16-21. 1-15.

Lotfi, S., Habibi, K., and Koohsar, M.J. (2011). An analysis of urban land development using multi-criteria decision model and geographical information system. Arabian J. Geosci., 4(3-4), 463-473.

Ma, Y. (2004). L-THIA: A useful hydrologic impact assessment model. Nat. Sci., 2(1), 68-73.

Makhdoum, M.F. (2007). Fundamental of land use planning, 7th edn.
Univ. Tehran Press. Tehran. 351 pp.

Malczewski, J. (1999). Multi Criteria Decision Analysis, John Wiley and Sons, Canada, 414pp.

Malczewski, J. (2006). GIS-based multicriteria decision analysis: a survey of the literature. Int. J. Geogr. Inf. Sci., 20(7), 703-726. http://dx.doi.org/10.1080/13658810600661508

McGarigal, K., and Marks, B.J. (1995). FRAGSTATS: spatial pattern analysis program for quantifying landscape structure. USDA For. Serv. Gen. Tech. Rep. PNW-351.

Mohammadi, J., and Shataee, S. (2010). Possibility investigation of tree diversity mapping using Landsat ETM+ data in the Hyrcanian forests of Iran. Remote Sens. Environ., 114(7), 1504-1512. http: //dx.doi.org/10.1016/j.rse.2010.02.004

Naghibi, F., and Shirmohammadi, H. (2008). Physical spatial development: A GIS analysis with emphasis on environmental impacts-Case study Nalos City, Iran. Iran. J. Environ. Health. Sci. Eng., 5(1), 43-50.

Pijanowski, B.C., Gage, S. H., and Long, D.T. (2000). A Land Transformation Model: Integrating Policy, Socioeconomics and Environmental Drivers using a Geographic Information System; In Landscape Ecology: A Top Down Approach, Larry Harris and James Sanderson eds.

Poelmans, L., Rompaey, A.V., Batelaan, O. (2010). Coupling urban expansion models and hydrologic models: How important are spatial patterns? Land Use Policy, 27, 965-975. http://dx.doi.org/ 10.1016/j.landusepol.2009.12.010

Ponce, V.M., and Hawkins, R.H. (1996). Runoff curve number: Has it reached maturity? J. Hydrol. Eng., 1(1), 11-19. http://dx.doi.org/10. 1061/(ASCE)1084-0699(1996)1:1(11)

Pontius, R., Boersma, W., Castella, J.C., Clarke, K., Nijs, T., Dietzel, C., Duan, Z., Fotsing, E., Goldstein, N., Kok, K., Koomen, E., and Lippitt, C. (2008). Comparing the input, output, and validation maps for several models of land change. Ann. Reg. Sci., 42(1), 11-37. http://dx.doi.org/10.1007/s00168-007-0138-2

Postel, S.L., Daily, G.C., and Ehrlich, P.R. (1996). Human appropriation of renewable freshwater. Science, 271, 785. http://dx. doi.org/10.1126/science.271.5250.785

Qi, H., Altinakar, M.S., Vieira, D. A.N., and Alidaee, B. (2008). Application of Tabu search algorithm with a coupled ANNGNPSCCHE1D model to optimize agricultural land use. J. Am. Water Resour. As., 44(4), 866-878. http://dx.doi.org/10.1111/j.1752-1688. 2008.00209.x

Randhir, T.O., and Tsvetkova, O. (2011). Spatiotemporal dynamics of landscape pattern and hydrologic process in watershed systems. $J$. Hydro. 404, 1-12. http://dx.doi.org/10.1016/j.jhydrol.2011.03.019

Randhir, T.O., O'Connor, R., Penner, P.R., and Goodwin, D.W. (2001). A watershed-based land prioritization model for water supply protection. Forest Ecol. Mange., 143, 47-56. http://dx.doi.org/10. 1016/S0378-1127(00)00504-1

Richert, M., Bianchin, S., Heilmeier, H., Hammer, G., Merta, M., and Seidler, C. (2007). Flood prevention and nature conservation in the Weisseritz area (Eastern Erzgebirge, Saxony, Germany), Interdisciplinary evaluation of land use scenarios. International Scientific Conference, Pol'ana nad Detvou, Slovakia, September 17 - 20.

Roberts, A.D., and Prince, S.D. (2010). Effects of urban and non-urban land cover on nitrogen and phosphorus runoff to Chesapeake Bay. Ecol. Indicators, 10(2), 459-474. http://dx.doi. org/10.1016/j.ecolind.2009.07.017

Roccasalva, G., Lami, L., and Lombardi, P. (2007). A spatial decision support system for strategic urban redevelopment. The case study of Turin Central Station, Italy. International Conference on Whole Life Urban Sustainability and its Assessment. Glasgow. UK.

Saaty, T.L. (1980). The Analytic Hierarchy Process: Planning, Priority Setting, Resource Allocation, McGraw-Hill. 281 pp. 
Scanlon, B.R., Jolly, I., Sophocleous, M., and Zhang, L. (2007). Global Impacts of Conversions from Natural to Agricultural Ecosystems on Water Resources: Quantity versus Quality. Water Resour. Res., 43(3), 1-18. http://dx.doi.org/10.1029/2006WR0054 86

Sher Jamal Khan, M.A., Aslam, I., and Zahiruddin, K. (2011). Simulation of the impacts of land-use change on surface runoff of Lai Nullah Basin in Islamabad, Pakistan, Landscape and Urban Planning, In Press, Corrected Proof, Available online 14 June 2011, ISSN 0169-2046. http://dx.doi.org/10.1016/j.landurbplan.2011.05. 006

Shiklomanov, I.A. (1999). Total global saltwater and freshwater estimates. State Hydrological Institute (SHI, St. Petersburg) and United Nations Educational, Scientific and Cultural Organisation (UNESCO, Paris)

Silva, E.A., and Clarke, K.C. (2002). Calibration of the SLEUTH urban growth model for Lisbon and Porto, Portugal. Comput. Environ. Urban, 26(6), 525-552. http://dx.doi.org/10.1016/S01989715(01)00014-X

Su, W., Gu, C., Yang, G., Chen, S., and Zhen, F. (2010). Measuring the impact of urban sprawl on natural landscape pattern of the Western Taihu Lake watershed, China. Landscape Urban Plann., 95(1-2), 61-67. http://dx.doi.org/10.1016/j.landurbplan.2009.12. 003

Svoray, T., Bar, P., and Bannet, T. (2005). Urban land-use allocation in a Mediterranean ecotone: Habitat Heterogeneity Model incorporated in a GIS using a multi-criteria mechanism. Landscape Urban Plann., 72, 337-351. http://dx.doi.org/10.1016/j. landurbpl an.2004. 05.001

Tang, Z., Engel, B.A., Pijanowski, B.C., and Lim, K.J. (2005). Minimizing the impact of urbanization on long term runoff. J. Am. Water Resour. Assoc., 41(6), 1347-1359. http://dx.doi.org/10.1111/j. 1752-1688.2005.tb03804.x

Arthur-Hartranft, S.T., Carlson, T.N., Clarke, K.C. (2003). Satellite and ground-based microclimate and hydrologic analyses coupled with a regional urban growth model. Remote Sens. Environ., 86(3), 385-400. http://dx.doi.org/10.1016/S0034-4257 (03)00080-4
Tudes, S. (2012). Correlation between Geology, Earthquake and Urban Planning. 417-434. in Earthquake Research and Analysis Statistical Studies, Observations and Planning, Ed. by Sebastiano D'Amico, ISBN 978-953-51-0134-5, 460 pp. Publisher: InTech.

UNESCO, (2010). Waterway Project. http://webworld.unesco.org/ water/ihp/publications/waterway/webpc/definition.html (accessed 20 November 2010)

USDA. (1986). Urban Hydrology for Small Watersheds. 164p.

USDA-SCS. (1985). National Engineering Handbook, Section 4 Hydrology. Washington, D.C.: USDA-SCS.

Verburg, P.H., Soepboer, W., Limpiada, R., Espaldon, M.V.O., Sharifa, M.A., and Veldkamp, A. (2002). Modelling the spatial dynamics of regional land use: The CLUE-S model. Environ. Manage., 30, 391-405. http://dx.doi.org/10.1007/s00267-002-2630 $-\mathrm{X}$

VMAP0 and VMAP1 Data Set. Www.mapability.com, accessed June 2010.

Weatherhead, E.K., and Howden, N.J.K. (2009). The relationship between land use and surface water resources in the UK. Land Use Policy, 26(1), 243-250.

White, M.D., and Greer, K.A. (2006). The effects of watershed urbanization on the stream hydrology and riparian vegetation of Los Penasquitos Creek, California. Landscape and Urban Plann., 74(2), 125-138. http://dx.doi.org/10.1016/j.landurbplan.2004.11.0 15

Yang, B., and Li, M.H. (2011). Assessing planning approaches by watershed streamflow modeling: Case study of The Woodlands; Texas. Landscape and Urban Plann., 99(1), 9-22. http://dx.doi.org/ 10.1016/j.landurbplan.2010.08.007

Yeo, I.Y., Gordon, S.I., and Guldman, J.M. (2004). Optimizing patterns of land use to reduce peak runoff flow and nonpoint source pollution with an integrated hydrologic and land use model. Earth Interact., 8(6), 1-20. http://dx.doi.org/10.1175/1087-3562(20 04)008<0001:OPOLUT $>2.0$. CO;2

Zadeh, L.A. (1965). Fuzzy Sets. Inform. Control, 8(1), 338-353. http://dx.doi.org/10.1016/S0019-9958(65)90241-X 